\title{
Van Rensselaer Potter: An Intellectual Memoir
}

\author{
PETER J. WHITEHOUSE
}

\section{Introduction}

Van Rensselaer Potter was the first voice to utter the word "bioethics," yet he is too little appreciated by the bioethics community. My expectations for my first visit with Professor Van Rensselaer Potter were primed by conversations with leaders and historians of the field of biomedical ethics, including Warren Reich, Al Jonsen, and David Thomasma. When mentioning my interest in environmental ethics and my concerns for the current state of biomedical ethics, I was told that I must meet Van. On my first visit to Madison, Wisconsin, Van met me at the McArdle Laboratories for Cancer Research at the University of Wisconsin, where he spent essentially his entire academic career as a basic oncological researcher. He was dressed informally and driving a rusting1984 Subaru station wagon with a license plate that read YES ZPG. We spent this first portion of our visit at the Institute where he is an Emeritus Professor and has contributed to understanding cancer metabolism as recognized by his election to the National Academy of Sciences. However, Van felt most at home in his shack located outside Madison. This country retreat included a rather primitive hut surrounded by acres of property owned by the family. I felt at the heart of Van's world when I sat in one of a pair of inexpensive plastic outdoor chairs in a particularly secluded part of the woods on the property, the place where Van himself communed with nature. Although during my initial and subsequent visits I met one of Van's sons, I never actually met his wife, Vivian, who was so central to his personal and family life. Tragically disabled by arthritis, Vivian's inability to easily leave the house, let alone travel, was one key reason for Van's commitment to staying in his own community.

Van was born in North Dakota and obtained his early college training at the State University. After some training in Europe, he spent the major portion of his career at the McArdle Laboratories for Cancer Research, where he became the Hillsdale Professor Emeritus of Oncology. He served in several prestigious national organizations, including the Association of Cancer Oncologists and the National Academy of Sciences.

\section{Key Concepts in Van Rensselaer Potter's Conception of Bioethics}

As documented by Warren Reich, ${ }^{1}$ Van Rensselaer Potter was the first to coin the term "bioethics" in 1970. Although arguments can be made for bilocated birth (e.g., also by Sargent Shriver in the development of the Kennedy Institute 
of Ethics), it seems clear that Van coined, used, and published the term prior to its use in Washington. The accuracy of the historical reconstruction is not nearly as important, however, as the fundamental differences between Potter's conceptions of bioethics and what has become the dominant form of thought of current day biomedical ethics. Potter's ethics were inspired by a profound understanding of biology generally, as well as by a deep personal concern about the survival and sustainability of life on the planet. Thus, although Potter explored the clinical implications of his work in bioethics, he was more concerned about basic relationships between biology and human values than just those issues raised by the "advances" of clinical and scientific medicine. Potter's interest in values and biology were primed by his knowledge of cancer biology and by the implications of uncontrolled growth of cells and life forms in general. His fundamental scientific contributions to understanding the metabolism of cancer cells enabled him to see the complexities of biological systems and their roles in human life.

Although Potter never met Aldo Leopold, a fellow faculty member at the University of Wisconsin, he was inspired by him and, in fact, dedicated his second book to Leopold, who had constructed the concept of "land ethics," an early, modern articulation in the West of an environmental ethic. ${ }^{2}$ As with Leopold, Potter was essentially concerned with developing an ethic that would guide behavior to permit the survival of human and other species. Potter's bioethics was explicitly future oriented, and as the title of his first book, Bioethics, Bridge to the Future, ${ }^{3}$ suggests, Potter considered the development of the field of bioethics as an essential aspect of human survival. Potter's ethics from the beginning were comprehensive and became even more so as he evolved the notion of a global bioethics. As Warren Reich points out, the concept of "global" has several meanings. The first is the idea that a bioethic needs to encompass concern about diverse ecosystems and human cultures. Potter's bioethic was also intellectually comprehensive and incorporated a variety of domains of ethical deliberation beyond those associated with clinical medicine. Perhaps most important in differentiating Potter's bioethics from other forms of biomedical ethics is the personal creed published in his works and lived in his life. Identifying oneself as a true Potterian bioethicist requires one to adopt certain personal stances toward environmental stewardship, including the use of resources, population control, and commitment to sustainability.

A particularly endearing capability of Potter was his ability to construct words to capture complex concepts. During my work with him over the past 5 years I saw him invent and try out several new words to describe his form of bioethics. We coined together the term "deep bioethics" as a blend of deep ecology and global bioethics. ${ }^{4}$ Global bioethics as a metaphor communicates both a sense of concern about the entire planet and about the comprehensiveness of the intellectual system. Deep ecologists ask us to reflect about our spiritual connections to the natural world just as Leopold did, for example, in his famous essay about looking into the eyes of a dying wolf. Thus, there is something explicitly spiritual about Potter's ethic that requires some kind of sacred connection to natural systems relating perhaps to E. O. Wilson's concept of biophilia. When coining the term "deep bioethics," we had a eureka feeling together, just as Potter described his original mental state, while riding his bicycle, when he first thought of the term "bioethics." During my association 
with Van Potter, he also experimented with the term "privilege ethic" to focus on the problems that divide the haves and have-nots in our world. Potter also considered the notion of a "bridge ethics" to focus on the need to connect different forms of medical, environmental, social, and religious ethics. Most recently, he worked to evolve a notion of sustainable ethics. However, at the root of all of his neologisms is his original conception of bioethics itself.

\section{Recent Efforts of Van Rensselaer Potter}

Several attempts have been made to understand why Potter's conception of bioethics to this point has not influenced the development of mainstream biomedical ethics to what some of us would consider an appropriate degree. The identification of the word "bioethics" with the Kennedy Institute closer to the heart of power in Washington, D.C., allowed it greater influence in clinical medicine. In the 1970s people were concerned about the implications of medical technology, particularly reproductive technology. This focus on the ethical implications of medical "breakthroughs" on human values continues to dominate much of biomedical ethics. The tragic lack of concern in our healthcare "systems" for environmental and public health could likely be associated with the same social forces that led to ignoring Potter's formulation of bioethics, such as short-term, profit-oriented, high-tech, genetically based acute medicine. Ironically, Potter has received much more recognition outside the United States as a major force in bioethics, perhaps because of the greater wisdom in other countries about long-term health issues.

Prior to his recent death, ${ }^{5}$ Potter's efforts focused around a group of international bioethicists with concerns about the sustainability of human life and the quality of our environment. I am fortunate to be a member of this group, which includes others from Europe, Asia, and South America. Under the direction of Cal DeWitt, Dr. Potter was working with us toward creating a Center for Bioethical Sustainability at the University of Wisconsin.

As our world population continues to increase, species continue to be eliminated, and concern for environmental health grows, it is likely and desirable that Potter's bioethics will achieve greater prominence. On the other hand, concerns about the professionalization of ethics around certain limited conceptions of medical ethics will also continue. The focus on individual autonomy as a dominant ethical principle in the United States must shift to broader issues of community responsibility and environmental stewardship. Potential devastating effects of conflict of interest may result if bioethics becomes too closely aligned with business. The resurgence of virtue ethics may generate interest in Potter's notion that being a bioethicist requires the adoption of personal values and behaviors consistent with his or her intellectual belief system.

In my view (influenced by Potter), our healthcare systems are unhealthy. Our almost-psychotic fixation with the power of controlling our own genetic makeup and those of other species is a major source of concern about the ultimate contributions of Western medicine and, particularly, multinational drug companies to the long-term viability of human life. It is time for bioethicists to ask more penetrating questions about the goals of our research and care systems. If we consider that an underlying goal of medicine is to promote the survival of human and other life on the planet, then Potter's conceptions of bioethics 
deserve a renaissance. This will require a wisdom not yet evident in our healthcare systems but called for in Potter's ethics. Potter was truly prescient in calling for bioethics as a bridge to the future, for without the kind of bioethical thinking that Potter pioneered we may not have a future.

\section{Notes}

1. Reich WT. The word "bioethics": the struggle over its earliest meanings. Kennedy Institute of Ethics Journal 1995;5(1):19-34.

2. Potter VR. Global Bioethics: Building on the Leopold Legacy. East Lansing: Michigan State University Press, 1988

3. Potter VR. Bioethics, Bridge to the Future. Englewood Cliffs, N.J.: Prentice-Hall, 1971.

4. Potter VR, Whitehouse PJ. Deep and global bioethics for a livable third millennium. The Scientist 1998;12(1):9.

5. Whitehouse PJ. In memoriam: Van Rensselaer Potter: the original bioethicist. The Hastings Report 2001;31(4):12. 